\title{
PEMBERIAN PROTEIN YANG ADEKUAT MEMPERCEPAT PENUTUPAN BURST ABDOMEN PADA PASIEN GERIATRI DENGAN TUMOR KOLON
}

\author{
Rosdiana R ${ }^{1}$, Agussalim Bukhari ${ }^{2}$, Nurpudji Astuti ${ }^{3}$, Mardiana Madjid ${ }^{4}$ \\ ${ }^{1}$ Departemen Gizi Klinis, Fakultas Kedokteran Universitas Hasanuddin, Makassar \\ email : rosdianasyahruddin@yahoo.co.id \\ ${ }^{2}$ Departemen Gizi Klinik Fakultas Kedokteran Universitas Hasanuddin, Makassar \\ email :agussalimbukhari@yahoo.com \\ ${ }^{3}$ Departemen Gizi Klinik Fakultas Kedokteran Universitas Hasanuddin, Makassar \\ email : pudji_taslim@yahoo.com \\ ${ }^{4}$ Departemen Gizi Klinik Fakultas Kedokteran Universitas Hasanuddin, Makassar \\ email : mardianamajid72@gmail.com
}

\begin{abstract}
Abstrak
Pendahuluan

Burst abdomen adalah terpisahnya jahitan luka pada abdomen secara parsial atau komplit salah satu atau seluruh lapisan dinding abdomen pada luka post operatif disertai protrusi dan eviserasi isi abdomen yang merupakan komplikasi tindakan bedah karena tidak adekuatnya perawatan luka, pengobatan, dan dukungan nutrisi.
\end{abstract}

\section{Resume kasus}

Seorang laki-laki berumur 85 tahun, dikonsul dari bagian bedah digestif dengan diagnosis medis Burst abdomen post operasi laparatomi dan colostomi et causa tumor colon rectosigmoid, keluhan utama luka terbuka di perut dan asupan tidak adekuat, Riwayat penurunan berat badan kurang dari $5 \mathrm{~kg}$ selama 1 bulan terakhir. Buang air besar via colostomi. Pemeriksaan antropometri didapatkan LLA $18 \mathrm{~cm}$. Pada pemeriksaan fisik ditemukan, anemia (+), Loss of subcutaneus fat (+), terdapat wasting pada keempat ekstremitas. Pemeriksaan laboratorium didapatkan deplesi berat sistem imun (874), hipoalbuminemia (2.6), anemia (9.6) dan hipokalemia (2.9). Kebutuhan Energi Terkoreksi : 1394 kkal dengan komposisi makronutrien: Protein: 1,7 gr/kg BBI/hari = $79.92 \mathrm{gr}=22 \%$, Karbohidrat : $55 \%=192,5 \mathrm{gr}$, Lemak : $23 \%=35,7 \mathrm{gr}$. Penatalaksanaan nutrisi perioperatif yang diberikan bertujuan sebagai manajemen nutrisi perioperatif, meningkatkan status gizi dan memperbaiki status metabolik pasien, mempercepat penyembuhan luka dan memberikan edukasi gizi ke pasien. Operasi repair wound dilakukan dengan nilai PNI 36,5.Pada hari ke-13 post operasi terjadi dehisensi luka. Peningkatan pemberian protein sebesar 2 gram $/ \mathrm{kgBBI} / \mathrm{hari}$ karena tidak adanya peningkatan kadar albumin. Setelah diintervensi pada hari ke 35 post operasi mulai terjadi perbaikan luka operasi. Pada pasien ini juga dilakukan program peningkatan berat badan( penambahan kalori secara bertahap dengan maksimal pemberian sebesar 1000 kkal) untuk perbaikan status gizi . Pada Monitoring dan evaluasi asupan membaik, antropometri terjadi peningkatan (LLA 20,5cm)dan pada pemeriksaan laboratorium didapatkan perbaikan kadar TLC (2.769), albumin $(3,8)$ dan kalium $(5,3)$ serta kadar $\mathrm{Hb}(11)$.Lama perawatan perioperatif 100 hari.

\section{Kesimpulan}

Intervensi nutrisi yang optimal, monitoring serta edukasi gizi diperlukan untuk menunjang perbaikan kondisi klinis pasien pre dan post operatif dengan burst abdomen. Intervensi nutrisi yang optimal, monitoring serta edukasi gizi yang baik menunjukkan adanya perbaikan asupan kalori, status metabolik sehingga dapat mengurangi risiko infeksi, lama rawat dan mortalitas yang berefek pada perbaikan luka.

Kata kunci : Nutrisi geriatri, burst abdomen, gizi buruk, hipoalbuminemia, hipokalemia. 


\section{Pendahuluan}

Burst abdomen atau disebut juga sebagai wound dehiscence merupakan komplikasi serius dari tindakan post operatif yang dapat meningkatkan morbiditas dan mortalitas (Soni, 2015). Menurut Swaroop et al. (2005) dan Kirshtein (2007) angka mortalitas pasien dengan burst abdomen rata-rata $0.4 \%$ sampai $3.5 \%$.

Burst abdomen adalah terbukanya tepi-tepi luka sehingga menyebabkan evirasi atau pengeluaran isi organ-organ dalam seperti usus, hal ini merupakan salah satu komplikasi post operasi dari penutupan luka di perut. Meskipun kasus ini jarang ditemukan di Indonesia namun tidak sedikit pasien yang pernah mengalami burst abdomen .

Burst abdomen berhubungan dengan tingginya angka kesakitan $>40 \%$ dan angka kematian $>18 \%$ pada lansia dan malnutrisi. Pada tahun 1972 terdapat 18 (3\%) kasus burst abdomen diantara 593 operasi yang terjadi pada anak-anak. Pada orang dewasa terdapat 45 kasus diantara 5156. Dari 45 kasus, $80 \%$ terjadi pada lansia. Perbandingan untuk pria dan wanita adalah $2: 1$. Namun, saat ini insiden burst abdomen tidak berbeda jauh dengan tahun 1972. Insiden sebanyak 0,2\% - 6\% dengan tingkat kematian $10 \%-30 \%$. Burst abdomen terjadi lebih sering terjadi pada pria daripada wanita. Biasanya terjadi pada minggu kedua, dengan puncaknya pada hari kesepuluh pasca-operasi (Gabrielle et al, 2014). Burst abdomen yang tidak ditangani dengan tepat dan segera dapat menimbulkan berbagai komplikasi yang serius yang akan meningkatkan resiko kematiaan.

$$
\text { Gabrielle (2014) menyatakan }
$$
bahwa etiologi burst abdomen 20\% persen disebabkan karena malnutrisi dan $11,9 \%$ disebabkan karena luka infeksi. Sinha et al. (2015) bahwa 65\% pasien dengan pre-operatif hypoalbuminemia, anemia, malnutrisi, penyakit saluran nafas dan operasi emergensi mengalami burst abdomen. Kejadian burst abdomen dapat dikurangi pada post operatif dengan meningkatkan status nutrisi pada pasien dan memberikan tindakan aseptik serta memperbaiki tekhnik operasi.

Nutrisi telah diketahui berperan penting dalam proses penyembuhan luka, dimana pada keadaan malnutrisi akan terjadi hambatan dalam proses normal penyembuhan luka. Keadaan ini dapat menimbulkan gangguan pada salah satu atau semua tahap-tahap penyembuhan luka seperti pemanjangan fase inflamasi, hambatan proliferasi fibroblast dan menurunnya sintesis kolagen. Selain itu, 
malnutrisi diketahui berkaitan dengan menurunnya kekuatan tegangan luka dan meningkatkan risiko infeksi. Jika keadaan malnutrisi berlangsung lama, maka dapat menimbulkan pressure ulcer, infeksi berat, dan hambatan penyembuhan luka yang berlangsung lama. Oleh karena itu, hambatan penyembuhan luka dapat meningkatkan risiko kesakitan dan kematian (Nelms MN,2007).

\section{Laporan Kasus}

Seorang laki-laki berumur 85 tahun, dikonsul dari bagian bedah digestif dengan diagnosis medis Burst abdomen post operasi laparatomi dan colostomi et causa tumor colon rectosigmoid, dengan keluhan utama luka terbuka di perut dan asupan tidak adekuat, Riwayat penurunan berat badan kurang dari $5 \mathrm{~kg}$ selama 1 bulan terakhir. Buang air besar via colostomi. Pemeriksaan antropometri didapatkan LLA $18 \mathrm{~cm}$. Pada pemeriksaan fisik ditemukan, anemia (+), Loss of subcutaneus fat $(+)$, terdapat wasting pada keempat ekstremitas. Pemeriksaan laboratorium ditemukan, deplesi berat sistem imun (874), hipoalbuminemia (2.6), anemia (9.6) dan hipokalemia (2.9). Terapi gizi diberikan bertujuan sebagai manajemen nutrisi perioperatif, meningkatkan status gizi dan memperbaiki status metabolik pasien, mempercepat penyembuhan luka dan memberikan edukasi gizi ke pasien.

Permasalahan pasien selama perawatan dapat disimpulkan sebagai berikut :

1. Burst abdomen dapat mengakibatkan gangguan metabolisme dan infeksi yang berisiko terjadi sepsis bahkan gagal fungsi organ yang dapat menyebabkan kematian.

2. Status gizi buruk disebabkan oleh asupan makanan yang tidak adekuat karena penurunan nafsu makan dan peningkatan kebutuhan nutrisi pada keadaan hipermetabolisme yang berkaitan dengan pembedahan.

3. Rendahnya nilai albumin serum yang akan mempengaruhi proses penyembuhan karena asupan yang kurang dan akibat peningkatan respon inflamasi sehingga sintesis albumin tidak adekuat.

4. Adanya anemia yang dapat memperburuk proses metabolisme nutrisi oleh karena $\mathrm{Hb}$ merupakan penghantar oksigen yang dibutuhkan untuk metabolisme makronutrien akibat asupan yang tidak adekuat dan perdarahan akut 
melalui luka sehingga

menimbulkan defisiensi

mikronutrien.

5. Nilai Total Lymphocyt Count (TLC) yang menurun karena penurunan sistem imun akibat status gizi kurang dan risiko infeksi yang dapat mengganggu proses penyembuhan.

6. Adanya gangguan keseimbangan elektrolit yang ditandai dengan rendahnya kadar kalium akibat asupan yang tidak adekuat.

7. Pengetahuan pasien dan keluarga mengenai gizi masih belum memadai.

\section{Terapi Gizi dan Monitoring}

Pasien didiagnosis status gizi buruk yang ditentukan dengan menggunakan parameter antropometri Lingkar Lengan Atas (LLA) berdasarkan persentasi LLA (Depkes). Pada pasien ini 61\%. Status metaboliknya adalah anemia normositik normokrom, deplesi berat sistem imun, leukositosis, hipoalbuminemia dan hipokalemia dan status gastrointestinal fungsional. Sehingga terapi gizi pada pasien tersebut adalah:

1. Memberikan asupan tinggi kalori dan tinggi protein

Kebutuhan energi untuk pasien ini berdasarkan rumus Harris-Benedict dengan faktor aktifitas 1,2 dan faktor stress 1,3 yaitu 1394 kkal . Komposisi makronutrien yang diberikan berupa protein 1,7-2,0 $\mathrm{gr} / \mathrm{kgBBI} / \mathrm{hari}$ sekitar $79,92-137,5$ gr $(22-25 \%)$ dengan pertimbangan adanya hipoalbuminemia dan untuk penyembuhan luka. Jumlah karbohidrat yang diberikan yaitu 192,5275 gr (50-55\%) dan lemak sekitar 35,760, 1 gr (23-25\%).

Pada pasien ini juga dilakukan program peningkatan berat badan ( penambahan kalori secara bertahap dengan maksimal pemberian sebesar 1000 kkal) untuk perbaikan status gizi. Terlihat bahwa dengan asupan yang adekuat terjadi peningkatan LLA sebesar $3,5 \mathrm{~cm}(22 \mathrm{~cm}$ pada awal pemeriksaan kemudian naik secara bertahap sampai $20,5 \mathrm{~cm}$ ), setelah perawatan 100 hari.

Pada awal dikonsul asupan makan berkurang sejak 1 bulan yang lalu dan memberat 2 minggu karena nafsu makan menurun. Hal ini disebabkan karena faktor psikologis, juga disebabkan karena adanya proses inflamasi terutama karena infeksi yang akan mengaktifasi pembentukan mediator inflamasi prostaglandin dari asam arakidonat yang akan menstimulasi neuropeptida CART/CRF/POMC dan menghambat neuropeptida NPY/AgRP sehingga menimbulkan rasa kenyang. 
Sitokin juga mempengaruhi motilitas dan pengosongan lambung melalui hambatan sinyal eferen yang mengatur nafsu makan dengan menghambat produksi leptin dan kolesistokinin (Madeddu. 2006).

Jenis asupan protein yang diberikan sebagian besar sebaiknya terdiri dari protein dengan nilai biologis tinggi (misalnya putih telur, daging putih) dan sisanya dikombinasi dengan protein nabati terutama dari kacang-kacangan, sedangkan kebutuhan lemak tidak lebih dari 30\% dari kebutuhan kalori total. Asupan vitamin dan mineral yang diberikan disesuaikan mencapai 5-10 kali AKG dengan cara memberikan suplementasi. Suplementasi yang diberikan berupa vitamin $\mathrm{C}$ 750mg/24jam, vitamin A 6000IU/8jam, vitamin B1 100mg, vitamin B6 200mg, vitamin B12 200mg, Zinc 20mg/24jam, , Curcuma $400 \mathrm{mg} / 8 \mathrm{jam}$ dan ekstrak ikan gabus(Pujimin $\left.{ }^{\circledR}\right) 2$ kapsul/8 jam.

Perbaikan asupan kalori pada hari ke-15 perawatan. Program peningkatan berat badan, kalori dinaikkan pada hari ke 20 perawatan sebesar 200 kkal secara bertahap hingga pada hari ke 40 mencapai 1000 kkal.

Pada awal perawatan diberikan diberikan 1,7 gram $/ \mathrm{kgBBI} / \mathrm{hari}$, namun pada hari ke 33 pemberian protein dinaikkan menjadi 2 gram $/ \mathrm{kgBBI} / \mathrm{hari}$
137,5 gram (25\%) karena kadar albumin tidak ada perbaikan bahkan terjadi penurunan(kadar albumin $3,1 \rightarrow 2,4$ ). Pada hari perawatan ke 56 dilkukan pemeriksaan UUN dan didapatkan hasil balance nitrogen $(+10)$ pada saat tersebut kadar albumin mencapai (3). Pada hari ke 99 terjadi azotemia dan pemberian protein diturunkan menjadi 1,75 gram/kgBBI/hari.

Pada awal perawatan $18 \mathrm{~cm}$, selama perawatan terjadi penurunan $17,8 \rightarrow 17,3 \rightarrow 17 \rightarrow 17,3 \rightarrow 17,6 \rightarrow 18 \rightarrow 18,5$ $\rightarrow 19 \rightarrow 19,5 \rightarrow 20$ dan diakhir perawatan $20,5 \mathrm{~cm}$.

2. Melakukan koreksi terhadap hipoalbuminemia

Proses penyembuhan dan luas permukaan luka dapat menyebabkan kehilangan asam amino bebas sehingga sering didapatkan penurunan kadar albumin. Pada pasien burst abdomen diberikan asupan protein yang lebih tinggi dengan harapan keseimbangan nitrogen menjadi positif untuk mempercepat proses terbentuknya jaringan baru yang rusak. Pasien ini memiliki kadar albumin rendah pada awal pemeriksaan yaitu 2,6 g/dl karena asupan yang tidak adekuat dan laju sintesis albumin meningkat akibat proses inflamasi.

Berdasarkan kadar albumin pasien ini yang rendah maka protein diberikan 
1,7-2,0gr/kgBBI/hari atau sebesar 75,9137,5gram/hari. Pemberian ini karena adanya proses inflamasi, dan fungsi ginjal yang masih normal. Jumlah ini dipenuhi dari asupan protein makanan baik hewani dan nabati dengan menambah porsi protein dengan nilai biologis tinggi seperti telur dan daging. Selain itu diberikan suplemen tambahan yaitu kapsul ekstrak ikan gabus (Pujimin $($ ) yang mengandung albumin dosis tinggi. Kadar albumin mecapai 3 gr/dL pada hari perawatan ke 66 dan menacapai 3,8 gr/dL dihari perawatan ke 97.

Kadar albumin diawal 2,6 gr/dL . Selama perawatan terjadi penurunan kadar albumin namun mecapai $3 \mathrm{gr} / \mathrm{dL}$ pada hari perawatan ke 66 dan menacapai 3,8 gr/dL dihari perawatan ke 97.

\section{Melakukan koreksi terhadap anemia}

Diagnosis anemia ditegakkan berdasarkan hasil pemeriksaan fisik dimana konjugtiva bulbi pasien tampak pucat dengan kadar hemoglobin $9.6 \mathrm{~g} / \mathrm{dL}$. Anemia kesan anemia normositik normokrom suspek kausa anemia penyakit kronik.

Anemia inflamasi yang disebut juga dengan anemia penyakit kronis biasanya berupa anemia yang ringan atau sedang (kadar hemoglobin jarang dibawah 8 g/dL) yang terjadi pada penyakit infeksi, inflamasi atau keganasan. Anemia penyakit kronis merupakan suatu kondisi yang dipengaruhi oleh inflamasi dan pelepasan sitokin (interleukin-1, interleukin-6, dan tumor necrosis factor). Protein inflamasi dari penyakit kronis akan menghambat reutilisasi zat besi, menurunkan eritropoesis, dan menurunkan produksi eritropeitin (Sobotka.2011 dan Fearon. 2011) .

Anemia yang terjadi dapat memperlambat proses perbaikan keadaan umum pasien dan meningkatkan kejadian infeksi sehingga penanganan anemia harus segera dilakukan pada pasien ini. Penatalaksanaan yang tepat untuk anemia pada pasien ini adalah menangani penyakit kronis dan inflamasi yang terjadi, dan memberikan dukungan nutrisi untuk pembentukan hemoglobin. Pada hari ke 12 perawatan terdapat penurunan kadar Hemoglobin menjadi $6.7 \mathrm{mg} / \mathrm{dl}$ namun pada akhir perawatan kadar hb mengalami perbaikan menjadi $11 \mathrm{~g} / \mathrm{dl}$.

Pada awal perawatan kadar haemoglobin 9,6 gram/dL dan selama perawatan terjadi penurunan kadar haemoglobin 6,7gram/dL. Namun setelah pemberian transfuse darah terjadi perbaikan, diakhir perawatan mencapai 11 gram/dL.

4. Memperbaiki Sistem Imun 
Diangnosis metabolic deplesi berat system imun ditegakkan berdasarkan pemeriksaan kadar TLC drum $874.5 \mathrm{ul} / \mathrm{dl}$. Deplesi sistem imun terjadi akibat adanya reaksi inflamasi oleh stress oksidatif sehingga terjadi pelepasan sitokin proinflamasi. Jumlah limfosit total merupakan salah satu parameter untuk melihat nilai fungsi sistem imun sebagai salah satu penilaian dalam status gizi. Jumlah limfosit total menunjukkan status protein viseral, sehingga dengan menurunnya jumlah limfosit menunjukkan adanya deplesi protein viseral, hal ini sejalan dengan kadar albumin yang merupakan parameter lain status protein viseral.

Gizi buruk dan infeksi melalui mekanisme penurunan sistem imun merupakan lingkaran yang harus diputus. Pada pasien ini adanya kondisi infeksi mengakibatkan penurunan status gizi yang berdampak pada semakin menurunnyasistem imunitas tubuh (ditandai dengan kadar limfosit yang rendah). Jumlah limfosit total merefleksikan sistem imunitas tubuh yang akan meningkatkan kerentanan pasien terhadap infeksi dan meningkatkan mortalitas. Manajemen nutrisi yang dilakukan adalah pemberian kecukupan energi, protein dan suplementasi zink, vitamin A dan vitamin C. Dengan intervensi nutrisi yang optimal tersebut, maka didapatkan kadar TLC yang meningkat pada perawatan hari ke 24 (1354.5 ul/dl) dan pada akhir perawatan. $(2769 \mathrm{ul} / \mathrm{dl})$.

Pada awal perawatan kadar TLC drum $874.5 \mathrm{ul} / \mathrm{dl}$ selanjutnya pada perawatan hari ke $24(1354.5 \mathrm{ul} / \mathrm{dl})$ dan pada akhir perawatan. $(2769 \mathrm{ul} / \mathrm{dl})$.

5. Melakukan koreksi terhadap hipokalemia

Pada 2 hr perawatan didaptkan kadar kalium mengalami penurunun, hal ini disebabkan selama ini sebelum masuk rumah sakit asupan makan pasien sangat kurang. Didapatkan kadar kalium 1.6 $\mathrm{mg} / \mathrm{dl}$ lalu dilakukan koreksi cepat dengan KCL $25 \%$ dan kadar kaium mengalami perbaikan menjadi $2.4 \mathrm{mg} / \mathrm{dl}$, selanjutnya dilakukan pemenuhan asupan kalium $1 \mathrm{meq} / \mathrm{kgbb}$, via oral dan akhir perawatan didapatkan kadar kalium 5.3 mg/dl.

Kadar kalium diawal perawatan 2,9. Selama perawatan terjadi penurunan kadar kalium

$1.6 \rightarrow 2,4 \rightarrow 1,8 \rightarrow 1,9 \rightarrow 1.6 \rightarrow 2 \rightarrow 2,1 \rightarrow 2,2 \rightarrow$ $2,4 \rightarrow 3,1 \rightarrow 3,6$ dan diakhir perawatan 
6. Memberikan

suplementasi

mikronutrien

untuk proses

penyembuhan luka

Defisiensi nutrien tertentu dapat menghambat proses penyembuhan luka. Efek negatif dari defisiensi nutrien atau malnutrisi pada penyembuhan luka terjadi dengan cara memperpanjang fase inflamasi, menurunan proliferasi fibroblast dan menghambat sintesis kolagen. Mikronutrien diperlukan dalam jumlah kecil per hari, namun mikronutrien berperan penting dalam metabolisme sel dan sebagai kofaktor enzim yang berperan dalam proses penyembuhan luka. Pada pasien luka bakar, sering dijumpai defisiensi mikronutrien akibat kebutuhannya meningkat di atas AKG.

Adapun peran beberapa mikronutrien dalam penyembuhan luka sebagai berikut: (Mac Kay. 2003) :

- Vitamin A dibutuhkan untuk pembentukan jaringan epitel dan tulang, pembelahan seluler serta fungsi imun. Penelitian mengenai pemberian vitamin A 50.000 IU/hari per oral atau 10.000 IU/hari per intramuskular, didapatkan perbaikan luka kronis semakin cepat

- Vitamin C atau asam askorbat, berperan dalam sintesis kolagen. Pada luka kronis yang luas, direkomendasikan

pemberian vitamin C sebesar 1000-2000 mg per oral untuk mempercepat proses penyembuhan luka. Pemberian vitamin $\mathrm{C}$ dosis tinggi harus diikuti dengan intake cairan yang cukup untuk mencegah pembentukan batu ginjal.

- Zink merupakan salah satu mikromineral yang berperan dalam berbagai metabolisme sel, penyembuhan luka dan memperbaiki sistem imun. Pada luka kronis, suplementasi zink dapat diberikan sampai $40 \mathrm{mg} /$ hari.

\section{Pengetahuan Gizi Kurang}

Kurangnya pengetahuan gizi pasien dan keluarga mengenai diet pada penyakit burst abdomen dan kebutuhan vitamin dan mineral pada pasien lansia, dapat memperburuk kondisi pasien, menyebabkan terjadinya komplikasi yang berat pada pasien. Pengetahuan yang baik, diharapkan sikap dan perilaku memilih makanan akan semakin baik sehingga komplikasi dari penyakit dapat dicegah.

\section{Kesimpulan}

Terapi gizi berdasarkan case burst abdomen pada pasien geriatri et causa tumor colon disertai malnutrisi berat, hipoalbuminemia dan hipokalemia 
dapat mengatasi proses inflamasi dan penyembuhan luka. Edukasi gizi dan dukungan keluarga dapat memperbaiki kondisi pasien.

\section{Daftar Pustaka}

1. Fearon K, Strasser F, Anker SD, Bosaeus I, Bruera E, Fainsinger RL, et al. Definition and Classification of Cancer Cachexia: An Internationalconsensus. Lancet Oncol 2011;12:489-95.

2. Gabrielle et al. 2014. Therapeutic Alternatives for Burst Abdomen.Surgical Technology International XIX.Erasmus Universitymedical Center Department Of Surgery Rotterdam, The Netherlands.

3. Kirshtein B, Roy-Shapira A, Lantsberg L, Mizrahi S. 2007. Use of TheBogota Bag for Temporary Abdominal Closure in Patients With Secondary Peritonitis.Am Surg;73:249-52.

Madeddu, Mantovani.phase II study with antioxidants, both in the diet and supplemented, pharmaconutritional support, progestagen, and anticyclooxygenase-2 showing efficacy and safety in patients with cancer-related anorexia/cachexia and oxidative stress. s.l. : Cancer Epidemiol Biomarkers Prev, 2006.

4. Nelms M, et al. 2007. Nutrition Therapy and Pathophysiology. 2nd edition.International edition. Wadsworth cengange learning.

5. Pradeep Soni et al. 2015. Burst Abdomen: A Post-operative Morbidity.International Journal of Scientifi c Study DOI: 10.17354/ijss/2015/417

6. Sinha A, Jayanth DH, Saurabh P, Srihari SR, Uthraa RT. 2015. Wounddehiscence still a post-operative morbidity: A retrospective study. JEvid Based Med Healthc;2:5712-7.

7. Sobotka L. Basics in clinical nutrition. Fourth edition. Prague: Galen. 2011.

8. Swaroop M, Williams M, Greene WR, Sava J, Park K, Wang D. 2005. MultipleTrauma. Am Surg 2005;71:4025.

9. Mac Kay D, Miller A. Nutritional support for wound healing. Alternative medicine review. 2003. 8 (4) : 359-77. 


\section{Asupan Kalori}

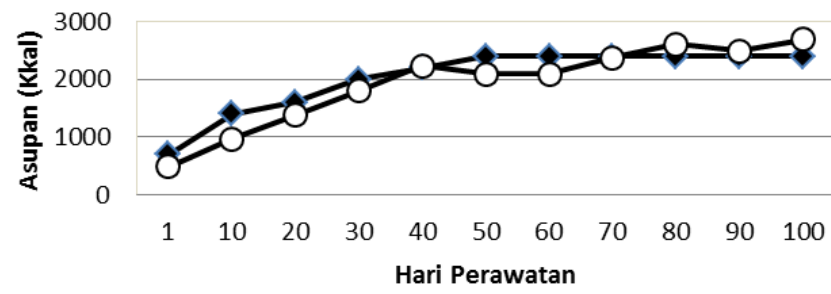

$\longrightarrow$-TARGET $\longrightarrow$-ASUPAN KALORI

Gambar 1. Asupan Kalori.

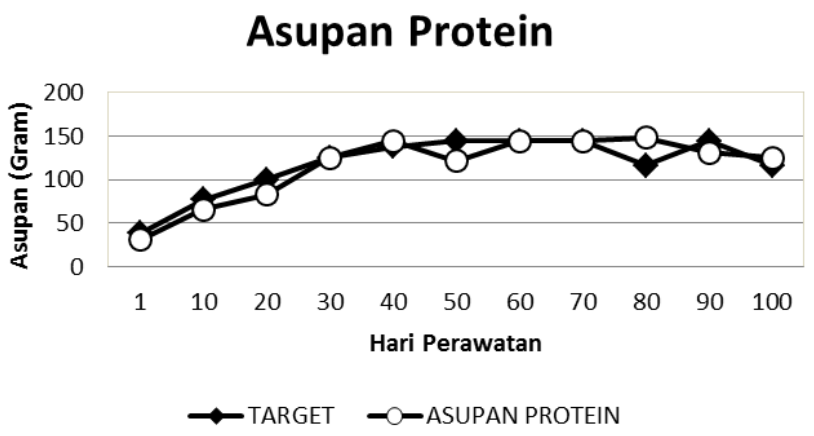

Gambar 2. Asupan Protein.

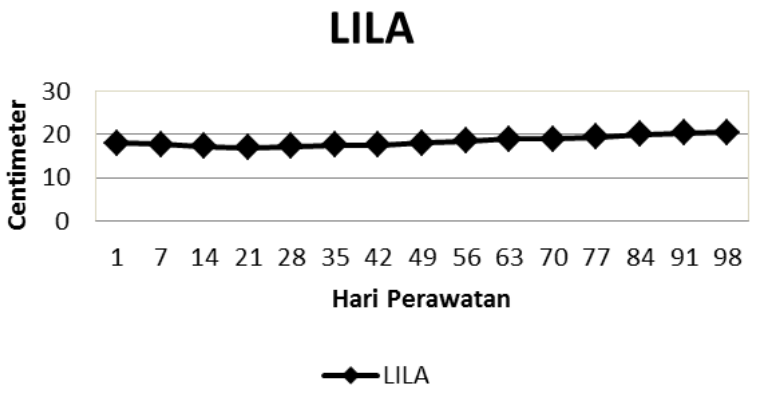

Gambar 3. Pengukuran LILA.

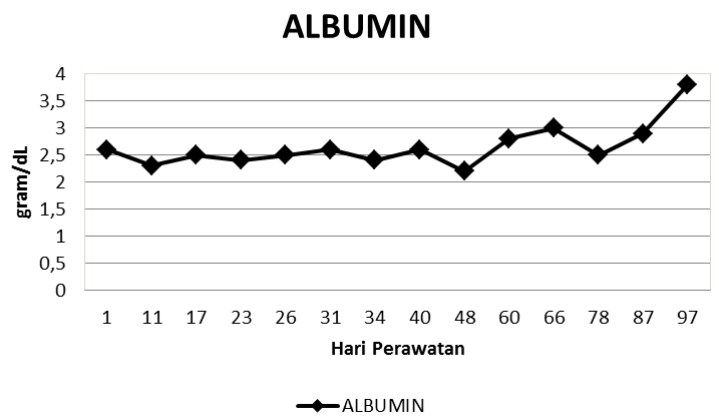

Gambar 4. Monitoring Kadar Albumin. 


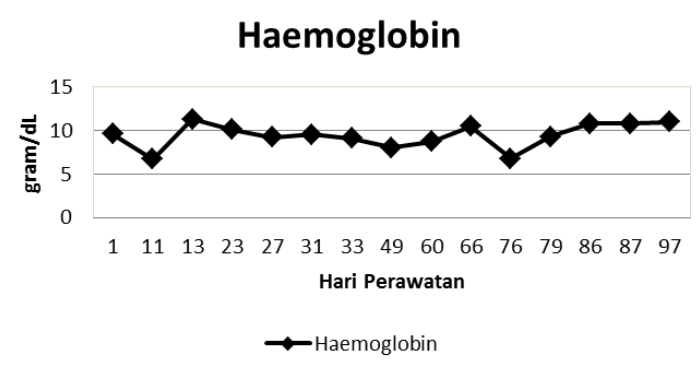

Gambar 5. Kadar Haemoglobin.

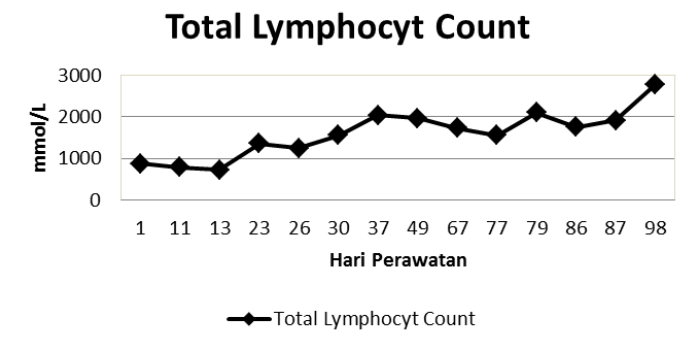

Gambar 6. Monitoring Kadar Total lymphocyt Count.

Kalium

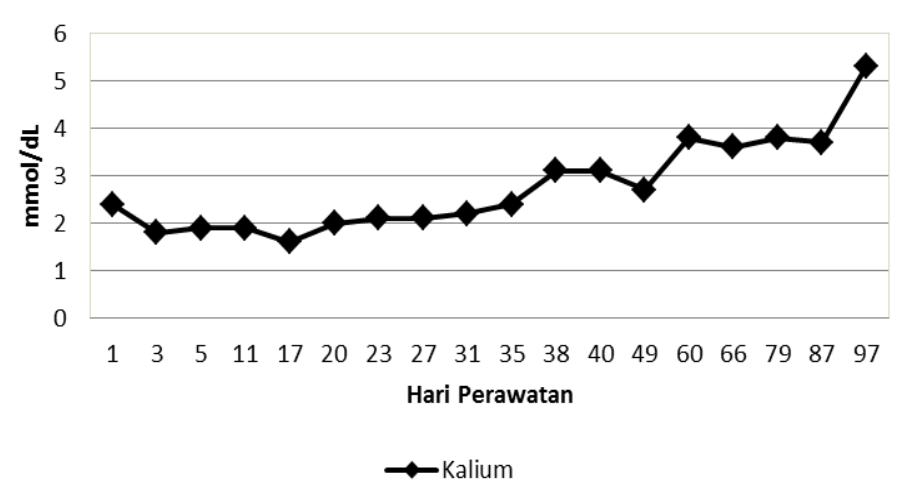

Gambar 7. Monitoring Kadar Kalium. 